\title{
Biochemical study on the meat and oil of Mongolian fishes
}

\author{
B.Chantsalnyam $^{1}$, Ch.Otgonbayar ${ }^{1}$, P.Odonmajig ${ }^{1}$, N.Tsevegsuren ${ }^{2}$ \\ ${ }^{1}$ Institute of Chemistry and Chemical Technology, MAS \\ ${ }^{2}$ School of Chemistry and Chemical Engineering, NUM \\ e-mail:chantsaa_001@yahoo.com
}

\begin{abstract}
The objective of this study was to determine the meat quality and fish oil's physical and chemical characteristics of the Mongolian fishes: Syrok (Coregonus peled), and Lenok (Brachymystax lenok). Lipid content was 3.1 to $14.15 \%$, moisture was 72.14 to $80.5 \%$, protein content was 8.54 to $9.8 \%$ and total mineral element was 0.5 to $3.1 \%$. The caloric value Lenok (Brachymystax lenok) was 68.7 and Syrok (Coregonus peled) - $142.8 \mathrm{Kj} / 100 \mathrm{~g}$, respectively. Minerals included potassium (46.32 to 52.22\%), phosphorous (39.06 to 41.3\%), calcium (3.26 to 5.87\%), magnesium (2.08 to $3.97 \%$ ) and silicon (1.14 to $2.24 \%$ ), while zinc, iron and copper were present intrace amounts. Eight non essential amino acids with total amount of 58.61 to $59.64 \%$ were identified, and histidine detected as in highest value in all the species, followed by arginine. The data showed that the Mongolian fishes are of high nutritional value and good source of proteins, minerals as well as non essential amino acids. The physical and chemical characteristics of Syrok (Coregonus peled), and Lenok (Brachymystax lenok) fish oil were analyzed. These parameters are: iodine value (IV), peroxide value (PV), acid value (AV), saponification value (SV), percentage of free fatty acid (\%FFA), refractive index (RI) and colour.

The extracted lipid content obtained from muscles of Syrok and Lenok was about 14.15\% and 3.1\%. The percentages of unsaturated fatty acids were higher than saturated fatty acids accounting for $74.37 \%$ and $25.6 \%, 83.83 \%$ and $16.46 \%$ respectively.
\end{abstract}

Keywords: Syrok (Coregonus peled), Lenok (Brachymystax lenok), protein, fish oil, macro- and micro-elements, amino acid, infrared spectrophotometer

\section{INTRODUCTION}

$\mathrm{F}$ Tish and other sea foods remain an important source of white meat for the human diet to its beneficial effect in reducing coronary heart diseases. This effects especially, due to the fat for the fish. Fishes living in fresh water and ocean are contained oils which used as food and in medicine. Fresh water's and ocean's fish oil are contained 14-35 highly unsaturated fatty acids. The fatty acid pattern of triacylglycerol and phospholipids of various fish oils were also assessed [1]. Epidemiological studies on the last assure that omega-3 fatty acids are derived from fish and fish oil to decrease the risk of coronary heart disease, hypertension and stroke, and their complications [2]. The liver obtained from fish has high pharmacological activity (serve as hypolipidemic agent an antiarthristic agent) [1]. It is known to be that Mongolia is rich in fishes. From ancient times Mongolian people have been used fish oil as food and remedy in traditional and physical treatment of some illnesses. Therefore, we have used fish Syrok (Coregonus peled) and Lenok (Brachymystax Lenok) which are widely distributed in Mongolia. The purpose of our study was biochemical study of meat obtained from two species of Syrok (Coregonus peled) and Lenok (Brachymystax Lenok)

\section{EXPERIMENTAL}

Methods. Moisture content was determined by gravimetric method. The ash content was determined by incinerating in a muffle furnance at $550^{\circ} \mathrm{C}$. Composition of the ash was measured 
by the using an X-ray fluorescence. The total protein and protein nitrogen amount were determined by the Kjeldahl method [1]. Amino acids were determined by paper chromatography method using standard amino acid as a standards [3]. The total lipid was determined by the Folch extract method [4].

\section{RESULTS AND DISCUSSION}

Biochemical characteristics of fish's meat is shown in table 1.

Table 1. Biochemical characteristics of Syrok's and Lenok's meat

\begin{tabular}{|c|c|c|c|c|}
\hline \multirow{3}{*}{ 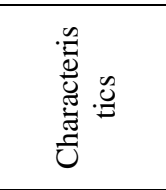 } & \multicolumn{2}{|c|}{$\begin{array}{c}\text { Syrok } \\
(\text { Coregonus peled }) \\
\end{array}$} & \multicolumn{2}{|c|}{$\begin{array}{c}\text { Lenok } \\
\text { (Brachymystax lenok) }\end{array}$} \\
\hline & $\begin{array}{c}\text { Our } \\
\text { research }\end{array}$ & $\begin{array}{l}\text { Kleimonov } \\
\text { et al }\end{array}$ & $\begin{array}{c}\text { Our } \\
\text { research }\end{array}$ & $\begin{array}{l}\text { Kleimonov } \\
\text { et al }\end{array}$ \\
\hline & Content & [5] & Content & [5] \\
\hline $\begin{array}{c}\text { Moisture } \\
(\%)\end{array}$ & 72.14 & $70-78 \%$ & 80.5 & - \\
\hline $\begin{array}{c}\text { Mineral } \\
\text { element }(\%)\end{array}$ & 2.95 & $1,3-1,5$ & 3.07 & 1.1 \\
\hline Protein $(\%)$ & 8.54 & $18-19.2$ & 9.8 & 18.2 \\
\hline Fat (\%) & 14.15 & $3,1-11$ & 3.1 & $3.8-7.7$ \\
\hline $\begin{array}{l}\text { Calories } \\
\text { (ccal) }\end{array}$ & 142.8 & 141.8 & 68.7 & 146 \\
\hline
\end{tabular}

A study result has been shown that the component of the minerals were $2.95 \%, 3.07 \%$; protein $-8.54 \%, 9.8 \%$; and fat $-14.15 \%, 3.1 \%$, respectively compared to result of study of Kleimonov. However, the lipid content in the meat of Syrok was relatively high $(14.15 \%)$. This is very valuable data and it is possible to be used as fat source. The concentration of mineral element was determined by using HORIBA X-ray Fluorescence analyzer MESA500W (at the Laboratory of Chemical Analysis, school of material and Technology, MUST).

The results of investigation were shown at table 2 and Fig $1 \mathrm{a}, \mathrm{b}$.

Table 2. Mineral content in meat of Syrok and Lenok

\begin{tabular}{|c|c|c|c|c|}
\hline \multirow{2}{*}{\multicolumn{2}{|c|}{ Elements }} & \multicolumn{3}{|c|}{ Content, $\%$} \\
\hline & & \multirow{2}{*}{$\begin{array}{c}\begin{array}{c}\text { Syrok } \\
\text { (Coregon } \\
\text { us peled) }\end{array} \\
3.97\end{array}$} & \multirow{2}{*}{$\begin{array}{c}\text { Lenok } \\
\text { (Brachymyst } \\
\text { ax lenok) }\end{array}$} & \multirow{2}{*}{$\begin{array}{c}\text { Oreochromis } \\
\text { niloticus [6] }\end{array}$} \\
\hline \multirow{5}{*}{ 总 莕 } & $\begin{array}{c}\mathrm{M} \\
\mathrm{g}\end{array}$ & & & \\
\hline & $\mathrm{Si}$ & 1.42 & 2.24 & \\
\hline & $\mathrm{P}$ & 41.30 & 39.06 & 35.7 \\
\hline & $\mathrm{K}$ & 46.32 & 52.22 & 36.48 \\
\hline & $\mathrm{Ca}$ & 5.87 & 3.26 & 4.1 \\
\hline \multirow{9}{*}{ 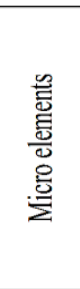 } & $\mathrm{Na}$ & 0.064 & - & 6.88 \\
\hline & $\mathrm{S}$ & 0.35 & - & - \\
\hline & $\begin{array}{c}\mathbf{M} \\
\mathbf{n}\end{array}$ & - & 0.01 & - \\
\hline & $\mathrm{Se}$ & - & - & 13.8 \\
\hline & $\mathrm{Fe}$ & 0.42 & 0.75 & 0.01 \\
\hline & $\mathrm{Cu}$ & 0.025 & 0.07 & 0.003 \\
\hline & $\mathrm{Zn}$ & 0.26 & 0.22 & 0.17 \\
\hline & $\mathrm{Al}$ & - & - & 0.08 \\
\hline & $\mathrm{Pb}$ & - & 0.06 & - \\
\hline
\end{tabular}

Ash content was emergenced by total 12 mineral elements in meat of Syrok and Lenok. The content of potassium was $(39.06 \%$, $52.22 \%)$ and phosphorium - $(41.30 \%, 46.32 \%)$, respectively. In all species the highest content calcium, magnium and siliconium were observed; the medium concentration - zinc, iron and copper - intrace amount.

The composition of mineral elements of Coregonus peled and Brachymystax lenok were similar to the mineral composition of Oreochromis niloticus.
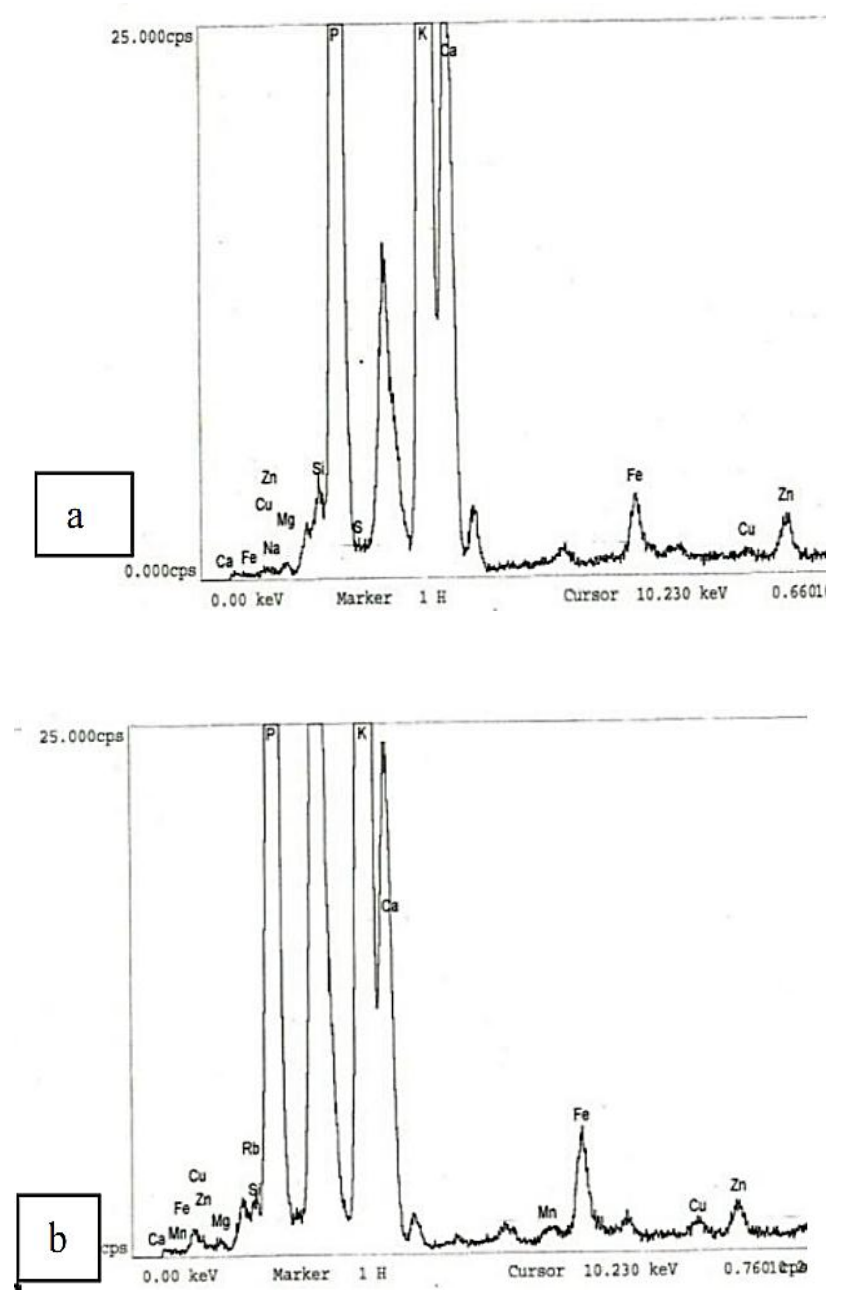

Figure 1. X-ray Fluorescence spectrum in meat of Syrok (a), Lenok (b)

The contents of free and protein amino acids were determined by paper chromatographic method, Results of study was shown in table 3 . From results of this study we detected totally 14 amino acids in protein of two fish's meat. There are 6 essential amino acids and 8 non essential amino acids. 
Table 3. The content of amino acids of Syrok's and Lenok's meat

\begin{tabular}{|c|c|c|c|}
\hline \multirow[t]{2}{*}{ № } & \multirow[t]{2}{*}{ Amino acids } & \multicolumn{2}{|c|}{$\begin{array}{c}\text { Estimated in } 100 \\
\text { g protein, } \%\end{array}$} \\
\hline & & Syrok & Lenok \\
\hline \multicolumn{4}{|c|}{ Essential amino acid } \\
\hline 1 & Cystine + Cysteine & 5.8 & 5.12 \\
\hline 2 & Clycine & 4.08 & 3.79 \\
\hline 3 & Alanine & 7.48 & 6.2 \\
\hline 4 & Aspartic acid & 6.24 & 10.05 \\
\hline 5 & Glutamic acid & 10.66 & 11.3 \\
\hline 6 & Serine & 6.02 & 4.87 \\
\hline & Total amino acids & 40.28 & 41.33 \\
\hline \multicolumn{4}{|c|}{ Non essential amino acid } \\
\hline 7 & Lysine & 7.74 & 6.37 \\
\hline 8 & Leucine & 7.09 & 6.54 \\
\hline 9 & Methionine & 4.68 & 4.15 \\
\hline 10 & Phenylalanine & 8.45 & 7.34 \\
\hline 11 & Tryptophan & 7.37 & 6.5 \\
\hline 12 & Valine & 6.54 & 6.16 \\
\hline 13 & Arginine & 9.6 & 8.47 \\
\hline 14 & Histidine & 8.17 & 13.08 \\
\hline & Total amino acids & 59.64 & 58.61 \\
\hline
\end{tabular}

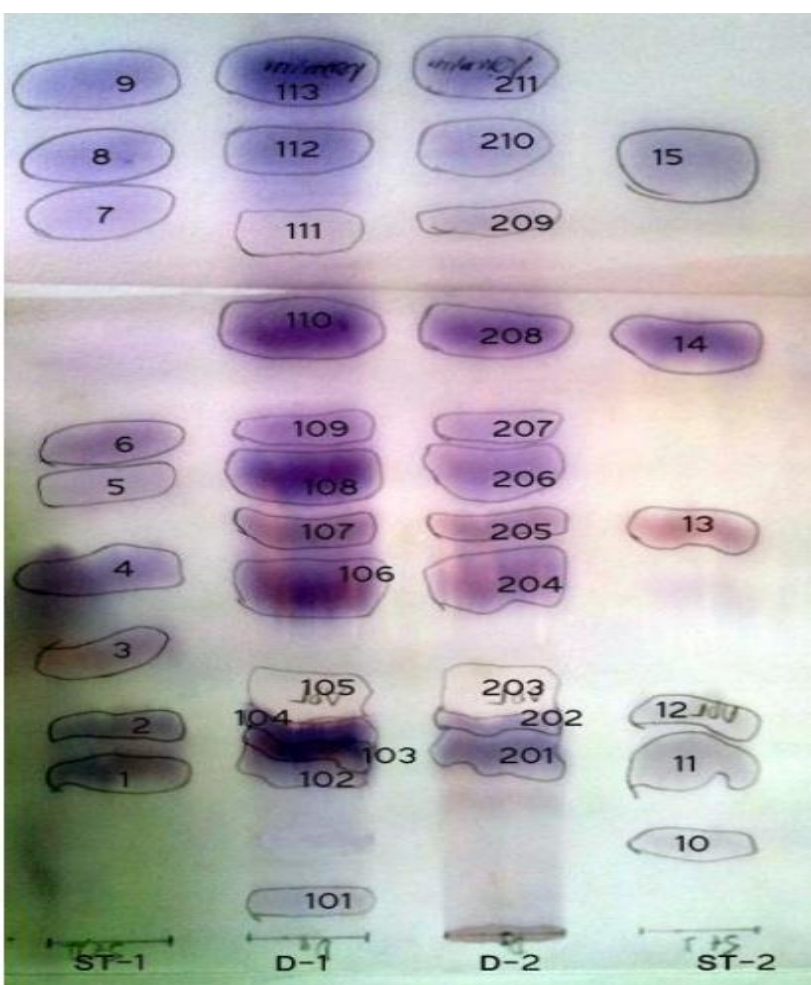

Figure 2. Chromatogram of amino acids

Table 5. The content of saturated and unsaturated fatty acids of fish's oil, \%

\begin{tabular}{|c|c|c|c|c|c|}
\hline & \multirow{2}{*}{$\begin{array}{c}\text { Weight of } \\
\text { fish oil, } \\
\text { Sample }\end{array}$} & \multicolumn{2}{|c|}{$\begin{array}{c}\text { Unsaturated } \\
\text { section }\end{array}$} & \multicolumn{2}{c|}{ Saturated section } \\
\cline { 3 - 6 } & $\mathrm{g}$ & $\begin{array}{c}\text { weight, } \\
\mathrm{g}\end{array}$ & $\begin{array}{c}\text { amount, } \\
\%\end{array}$ & $\begin{array}{c}\text { weight, } \\
\mathrm{g}\end{array}$ & $\begin{array}{c}\text { amount, } \\
\%\end{array}$ \\
\hline $\begin{array}{c}\text { Syrok } \\
\text { (Coregonus } \\
\text { peled })\end{array}$ & 8.0 & 5.95 & 74.375 & 2.05 & 25.625 \\
\hline $\begin{array}{c}\text { Lenok } \\
\text { (Brachymys } \\
\text { tax lenok })\end{array}$ & 3.230 & 2.698 & 83.838 & 0.532 & 16.462 \\
\hline
\end{tabular}

The results showed that the content of unsaturated fatty acid's in Syrok's and Lenok's oil were $74.37 \%, 83.83 \%$, respectively.

The protein are contained the highest value of glutamic $(10.66 \%, 11.3 \%)$, phenylalanine $(8.45 \%, 7.34 \%)$, arginine $(9.6 \%, 8.47 \%)$ and histidine $(8.17 \%, 13.08 \%)$; the total non essential amino acid ranged 58.61-59.64\%.

In generally, the quality of oil was determined by its chemical characteristics. Chemical characteristics in oil of twospecies of fishes are shown in table 4 . The results showed that the iodine value of Syrok's oil $\left(137.3 \mathrm{~J}_{2} \%\right)$ is relatively lower than lenok's oil $\left(207.6 \mathrm{~J}_{2} \%\right)$. This iodine value is depended on content of unsaturated fatty acids. On the other hand, unsaturated content of Syrok' oil was lower than lenok's oil.

Table 4. Chemical characteristics of fish oil

\begin{tabular}{|l|c|c|}
\hline \multicolumn{1}{|c|}{ Characteristics } & Syrok & Lenok \\
\hline Acid value $(\mathrm{mg} \mathrm{KOH} / \mathrm{g})$ & 2.4852 & 1.96 \\
\hline Iodine value $\left(\mathrm{J}_{2} \%\right)$ & 137.2881 & 207.6271 \\
\hline Saponification value $(\mathrm{mg} \mathrm{KOH} / \mathrm{g})$ & 168.7734 & 117.5815 \\
\hline Peroxide value $\left(\mathrm{mg} \mathrm{eq} \mathrm{H}_{2} \mathrm{O}_{2} / \mathrm{kg}\right)$ & 0.3543 & 0.6233 \\
\hline Esterification value $(\mathrm{mg} / \mathrm{g})$ & 166.2882 & 115.6215 \\
\hline
\end{tabular}

Infrared spectra of the fish's oil were obtained on FT-IR spectrophotometer (at the Associate Laboratory of Nature Science, MAS) for samples dispersed in $\mathrm{KBr}$ discs.

Figure 4 shows the infrared spectrum of the fish's oil (Syrok and Lenok). Among the absorption bands are observed common bands at $2950-3000 \mathrm{~cm}^{-1} \quad \mathrm{C}-\mathrm{C}-\mathrm{H}\left(\mathrm{sp}^{3}\right)$ (stretching vibration) and $1730-1750 \mathrm{~cm}^{-1} \mathrm{C}=\mathrm{O}$ (streching vibration of ester group), $1465 \mathrm{~cm}^{-1}-\mathrm{CH}_{2-}(\sigma)$ (stretching vibration) as well as at $665-730 \mathrm{~cm}^{-1}$ $\mathrm{RCH}=\mathrm{CHR}^{1} \quad$ (cis-orientation of double bond).This explanation of spectrogram shows the all unsaturated fatty acids presented in cisstereoisomer form in both oils.

\section{CONCLUSIONS}

1. The content of proteins and mineral elements of both fishes were similar. The Syrok's total oil amount was $14.15 \%$ and Lenok's - was $3.1 \%$. Ash content was emergenced by total 12 mineral elements in 
meat of Syrok and Lenok. The content of potassium was $(39.06 \%, 52.22 \%)$ and phosphorium - $(41.30 \%, \quad 46.32 \%)$, respectively

2. The Syrok's proten contained non essential amino acid 59.6\%, essential amino acid $40.2 \%$; the Lenok's protein - non essential amino acid is $58.6 \%$, essential amino acid is $41.3 \%$, respectively.

3. It is shown to be that Lenok' oil has high iodine value $\left(207.62 \mathrm{~J}_{2} \%\right)$ due to high amount of unsaturated fatty acids thereas Syrok' oil has low iodine value (137.28 $\mathrm{J}_{2} \%$ ).

4. The content of saturated and unsaturated fatty acids of the Syrok's and Lenok's oils were $25.6 \%, 16.5 \%$ and were - $74.4 \%$, $83.8 \%$, respectively.

\section{REFERENCES}

1. Saify S.S., Akhtar S., Khan, K.M., Perveen $S$ et al. 2003. A study on the fatty acid composition of fish oil from two Marine fish, Eusphyra blochii and carcharhinius bleekeri. Turk J Chem, 27:251-258.

2. Simopoulos A.P., 2002. Omega-3 fatty acids and cardiovascular disease: The epidemiological evidence. Environmental health and preventive medicine, 6:203-209.

3. Pleshkov B.P. (1985). Practices of phytochemistry. p 90-95, 238-240

4. http://www.cyberlipid.org/extract/extr0005. htm

5. Baasanjaw.G., Tsend-Ayush,Ya.,(2001). Fish of Mongolia. P. 24-27, 35-36

6. Elagba Mohamed, H.A., (2010). Proximate composition, amino acid and mineral contents of five commercial Nile fishes in Sudan. African Journal of Food Science, 4: 650-654. 